\title{
Pembelajaran Berbasis Applied Learning untuk Meningkatkan Bahasa Inggris MIM PK Kartasura
}

\author{
Fernanda Frisky Warhandika1), Dhevi Anastia $R^{2)}$, Danita Novian \\ Permatasari ${ }^{3)}$, \\ 1, 2, 3)Universitas Muhammadiyah Surakarta \\ 1)kikiwarhandika20@gmail.com ${ }^{2)}$ dhevianastia34@gmail.com \\ 3) danitapermata20@gmail.com \\ doi: $10.23917 /$ blbs.v2i1.11613
}

\begin{abstract}
Abstrak. Penelitian ini bertujuan untuk : 1) Mendiskripsikan Program SME dalam peningkatan kemampuan berbahasa inggris pada anak, 2) Mengidentifikasi Dampak positif dari program applied learning terhadap perkembangan kognitif pada siswa, 3) Mengetahui kesulitan apa saja yang ditemui guru dalam menerapkan metode pembelajaran berbasis Bahasa Inggris dan solusi mengatasi kesulitan. Penelitian ini menggunakan penelitian jenis kualitatif dengan pola deskriptif. Teknik pengumpulan data dengan observasi, wawancara dan dokumentasi. Keabsahan data dengan triangulasi teknik dan triangulasi sumber. Teknik analisis data penelitian dilakukan secara interaktif. Hasil penelitian menunjukkan bahwa: 1) Meningkatkan kemampuan Bahasa Inggris dengan menerapkan program vocabulary book, classroom language di terapkan sehari- hari sehingga siswa dapat menguasai bahasa inggris dan dapat menerapkannya ke dalam soal-soal yang berbasis Bahasa Inggris. Penerapannya seperti anak dapat menggunakan kalimat-kalimat perintah dalam Bahasa Inggris, dari hal-hal kecil siswa di biasakan untuk menggunakan Bahasa Inggris agar kemampuan siswa lebih banyak. 2) Dampak positif dari program applied learning terhadap perkembangan kognitif pada siswa. Siswa dapat mengembangkan kemampuan bahasa inggrisnya untuk berkompetisi dengan sekolah lain saat mengikuti olimpiade, siswa dapat menambah kosakata Bahasa inggris lebih banyak. ; 3) Kendala yang ditemui guru dalam menerapkan metode pembelajaran berbasis Bahasa Inggris adalah masih terdapat beberapa anak yang belum bisa menulis dan membaca Bahasa inggri dikelas rendah. Solusinya guru harus menentukan sendiri strategi pembelajaran yang digunakan dengan menyesuaikan kondisi anak usia SD.
\end{abstract}

Kata kunci:, Applied Learning, meningkatkan kemampuan Bahasa Inggris, model pembelajaran.

\section{PENDAHULUAN}

Suatu sekolah pasti memiliki suatu program untuk mengembangkan potensi yang dimiki siswa, menjaring, melatih agar siswa dapat berkompetisi di jenjang yang lebih luas, dan meningkatkan prestasi belajar melalui pembelajaran berbasis applied learnig. Kelas Science Math English (SME) merupakan sebuah program inovasi dengan mengembangkan bakat anak dalam bidang matematika dan sains yang dibekali dengan keterampilan bahasa inggris. Program SME di sekolah di tujukan agar peserta didik dapat menyalurkan minat bakat dan kemampuannya sehingga potensi-potensi yang terpendam dapat tersalurkan dengan baik. MIM PK Kartasura memiliki visi dan 
misi. Salah satu visinya yaitu terwujudnya benih kesalehan serta unggul dalam prestasi berdasarkan iman dan taqwa. Salah satu misi dari MIM PK Kartasura yaitu pendidikan madrasah yang manusiawi dengan suasana yang kondusif, senang belajar dan belajar dengan senang. Dalam proses pembelajaran Bahasa Inggris di kelas SME berbasis MI, guru berusaha untuk memahami potensi, kecerdasan dan karakteristik siswa agar tujuan dari pendidikan dapat tercapai secara optimal.

Pengembangan kecerdasan setiap siswa harus disesuaikan dengan potensi yang dimiliki siswa dengan pembelajaran yang efektif, efisien, dan produktif. Latar belakang adanya kelas SME berbasis MI yaitu tuntutan perkembangan zaman dengan adanya MEA yang mendorong generasi muda harus menguasai bahasa internasional atau bahasa Inggris dan rindunya sosok ilmuan muda yang menguasai bidang ilmu sains dan matematika. MI digunakan dalam penentuan gaya belajar yang disesuaikan dengan kecerdasan yang dimiliki setiap individu dideteksi melalui tes Multiple Intelligences Research (MIR).

Bahasa Inggris merupakan bahasa internasional dan bahasa resmi yang digunakan oleh berbagai negara dipenjuru dunia untuk berkomunikasi. Bahasa Inggris memegang peranan yang sangat penting. Pendidikan dan pembelajaran Bahasa inggris didasari suatu pemikiran bahwa belajar bahasa asing atau bahsa kedua akan lebih baik dimulai lebih awal (Hammerby, 1982:265).

Pelaksanaan pembelajaran student center learning atau pembelajaran yang berpusat pada siswa, yaitu menempatkan siswa sebagai subjek yang aktif dan mandiri, bertanggung jawab dalam kegiatan pembelajaran. Strategi pembelajaran yang digunakan beragam, seperti pengajaran interaktif (interactive teaching), yaitu guru sebagai komando siswa dalam pembelajaran dan guru bertanya siswa menjawab. Guru memberikan kebebasan dalam melakukan pengamalan dan penjelasan identifikasi pada suatu pembelajaran. Sehingga dalam pembelajaran guru melibatkan siswa secara aktif dan langsung dalam kegiatan pembelajaran sesuai dengan yang dikemukakan BG J. Tujuan dari penelitian ini adalah 1) Mendiskripsikan program SME dalam peningkatan kemampuan Berbahasa Inggris pada anak, 2) Mengidentifikasi dampak positif dari program applied learning terhadap perkembangan kognitif pada siswa, 3) Mengetahui kesulitan apa saja yang ditemui guru dalam menerapkan metode pembelajaran berbasis Bahasa Inggris. Teknik pengumpulan data yang digunakan berupa wawancara, observasi, dan dokumentasi. Penelitian ini mengunakan penelitian kualitatif dengan pola deskriptif. 
Penelitian deskriptif merupakan penelitian dengan penggambaran atau penjelasan secara nyata yang ada di MIM PK Kartasura. Penelitian ini diawali dengan pengumpulan data, Informasi yang diperoleh akan diolah agar bisa sesuai data deskriptif. Kemudian menarik kesimpulan dari informasi atau data yang diperoleh. Setelah analisis data, maka hasil penelitian dapat disimpulkan. Hasil penelitian yang disimpulkan harus sesuai dengan data di lapangan.

\section{METODE PENELITIAN}

Penelitian ini mengunakan penelitian kualitatif dengan pola deskriptif untuk menggambarkan hasil penelitian mengenai implementas pembelajaran Bahasa Inggris kelas SME MIM PK Kartasura. Menurut Sugiyono (2016:15) metode penelitian kualitatif merupakan metode penelitian yang berlandaskan pada filsafat, digunakan untuk meneliti pada kondisi obyek yang alamiah. Penelitian kualitatif merupakan penelitian yang mengumpulkan data dan menganalisis data dengan latar ilmiah serta tidak berusaha menghitung data atau tidak menganalisis angka.

Desain dari penelitian deskriptif kualitatif ini digunakan untuk mengetahui fakta dilapangan mengenai penerapan pembelajaran Bahasa Inggris kelas SME MIM PK Kartasura. Metode wawancara, observasi, dan dokumentasi merupakan teknik pengumpulan data yang digunakan oleh peneliti. Penelitian deskriptif merupakan penelitian dengan penggambaran atau penjelasan secara nyata yang ada di MIM PK Kartasura. Salah satu program pelaksanaan applied learning yaitu dengan membiasakan siswa menggunakan bahasa inggris dalam kegiatan sehari- hari di sekolah.

Kegiatan praktik sehari-hari menggunakan Bahasa Inggris dapat di mulai dari hal-hal yang kecil seperti menggunakan Bahasa inggris ketika izin dan saat memakai kata perintah. Setiap bulan sekali di minggu ketiga melakukan ulangan menggunakan Bahasa Inggris.

\section{HASIL PENELITIAN DAN PEMBAHASAN}

MIM PK Kartasura berdiri sejak tahun 1970. MIM PK Kartasura terletak di Jl. Slamet Riyadi 80, Kartasura, Sukoharjo, Jawa Tengah. MIM PK Kartasura memilki berbagai macam program, salah satunya Program Kelas SME (Science, Math and English), kelas tahfidz, kelas creative. Tujuannya menciptakan siswa yang siap berkomprtisi dalam olimpiade Science, Math and English. Dalam program ini anak diharapkan dapat mengembangkan kemampuan yang unggul dalam bidangnya 
masing-masing. Selain itu latar belakang dibentuknya program khusus di MIM PK Kartasura yaitu sebagai wadah untuk anakanak yang memiliki potensi berbedabeda. Selain itu banyaknya siswa yang berprestasi membuat guru untuk menciptakan wadah agar siswa dapat mengembangkan kemampuan yang dimiliki. Menyiapkan bibit-bibit unggul agar dapat berkompetisi dengan sekolah lain.

Dengan program SME khususnya Bahasa Inggris ini dapat melatih pengucapan, memahami tata bahasa, dan menguasai kosakata melalui program ini, guru juga melatih siswa dengan berbagai hal, misalnya membiasakan menggunakan kalimat Bahasa Inggris ketika berbicara dengan guru dan siswa lainya. Dalam program SME sudah berjalan selama 3 tahun sehingga sudah memperoleh 3 kelas yang diikuti dari kelas 1D hingga kelas 3D. Siswa memilih masuk program SME ini karena siswa dapat mengembangkan kemampuan Sains, Mathematic, and English. Dengan adanya program applied learning praktik menggunakan Bahasa Inggris di kelas dalam kegiatan seharihari diharapkan siswa dapat membiasakan berkomunikasi dengan Bahasa Inggris dan dapat memperbanyak kosakata sehingga siswa mampu mengerjakan soal-soal berbasis Bahasa Inggris. Dengan rutin menggunakan Bahasa Inggris dalam proses pembelajaran maupun kegiatan sehari-hari di sekolah dapat meningkatkan kemampuan kognitif pada siswa.

Bahasa Inggris merupakan bahasa internasional yang memiliki peranan penting dalam era millenial saat ini untuk berkomunikasi dengan masyarakat dunia. Penguasaan Bahasa Inggris pada anak sekolah dasar dapat ditunjang oleh beberapa faktor, yakni metode pembelajaran, sarana dan prasarana, serta materi pembelajaran. Afisa dan Yolanda (2015) meneliti bahwa faktor penyebab kesulitan dalam belajar berbicara bahasa Inggris adalah jumlah frekuensi praktek berbicara Bahasa Inggris dan faktor psikologi yaitu pada aspek afektif. Pada kenyataannya, di Indonesia masih dijumpai SD yang belum memaksimalkan faktor-faktor tersebut. Masih terdapat beberapa guru Bahasa Inggris mengajar dengan metode yang kurang tepat, sarana dan prasana sekolah kurang memadai serta materi pembelajaran Bahasa Inggris yang kurang kontekstual.

Dalam upaya pembelajaran ini siswa di harapkan dapat lebih mudah meningkatkan kemampuannya dalam berbahasa inggris, dengan menerapkan vocabulary book, classroom language. Contoh dari penerapan program classrom language dengan menggunakan intruksi bahasa inggris, berdoa menggunakan tiga bahasa yaitu bahasa arab, bahasa inggris, dan 
bahasa indonesia. Penerapan program ini di terapkan sehari-hari agar siswa dapat menguasai bahasa inggris dan dapat menerapkannya ke dalam soal-soal yang berbasis Bahasa Inggris. Penerapannya seperti anak dapat menggunakan kalimat-kalimat perintah menggunakan Bahasa Inggris, dari hal-hal kecil siswa di biasakan untuk menggunakan Bahasa Inggris agar kemampuan siswa lebih banyak. Satu bulan sekali melaksanakan ulangan menggunakan Bahasa Inggris.

Dampak positif dari program applied learning terhadap perkembangan kognitif pada siswa. Siswa dapat mengembangkan kemampuan bahasa inggrisnya untuk berkompetisi dengan sekolah lain. Dalam penerapannya, siswa SME pernah mengikuti beberapa lomba internasional seperti Kangaroo Science, SEAMO (Southeast Asian Mathematical Olympiad), TIMO (Thailand International Mathematical Olympiad). Kesulitan yang ditemui guru saat menerapkan metode pembelajaran degan Bahasa inggris yaitu masih terdapat siswa yang belum bisa membaca dan menulis menggunakan Bahasa Inggris pada grade bawah.

\section{SIMPULAN}

Program SME (Sains, Math and English) dapat menjadi landasan maupun sarana dan prasarana belajar siswa agar mampu mengembangkan kemampuan yang dimilki. Ada beberapa program yang diterapkan seperti, vocabulary book dan classroom language. Contoh classrom language yaitu menggunakan intruksi bahasa inggris saat di kelas, berdoa menggunakan tiga bahasa yaitu bahasa arab, bahasa inggris, dan bahasa indonesia. vocabulary book, classroom language. Dampak positif dari program applied learning terhadap perkembangan kognitif pada yaitu siswa dapat mengembangkan kemampuan bahasa inggrisnya untuk berkompetisi dengan sekolah lain. Ada beberapa kendala yang ditemui guru dalam menerapkan pembelajaran berbasis applied learning dengan Bahasa Inggris yaitu guru harus menentukan sendiri strategi pembelajaran yang akan digunakan dengan menyesuaikan kondisi anak usia SD. Selain itu masih terdapat beberapa anak yang belum bisa menulis dan membaca Bahasa Inggris di kelas rendah. Solusi dari kelompok kami adalah diharapkan guru memberikan jam tambahan untuk belajar membaca dan menulis agar dapat beradaptasi menggunakan Bahasa Inggris.

\section{DAFTAR PUSTAKA}

Haque, Rohiima. 2017. Peran Kepala Sekolah Dalam Mengembangkan Sekolah Unggul Di Madrasah Ibtidaiyah 
Muhammadiyah Program Khusus Kartasura. Strata 1. Program Studi Pendidikan Guru Sekolah Dasar. UMS.

Kusumajati, Putri A. 2018. Implementasi Pembelajaran IPA Berbasis Bahasa Inggris Di Kelas Sains, Mathematics, English (SME) MIM PK Kartasura. Strata 1. Program Studi Pendidikan Guru Sekolah Dasar. UMS.

Suhartatik, S. 2014. Pengembangan Model Project-Based Learning untuk Meningkatkan Kemampuan Bahasa Inggris Siswa Ponpes Modern di Malang. Jurnal Ilmu Bahasa dan Sastra. Vol. 9(2). 83-90.

Suryawan, M.A. 2016. E- Learning Pengenalan Alat Transportasi dalam Bhasa Inggris sebagai Media Pembelajaran Siswa SD. Jurnal Informatika. Vol. 5(1). 16-28.

Syahputra, Idham. 2014. Strategi Pembelajaran Bahasa Inggris sebagai Bahasa Asing dalam Meningkatkan Kemampuan Berbahasa Siswa. Jurnal Penelitian Sosial Keagamaan, Vol. 17(1). 127-145. 